\title{
Gender and intra-household migration decision in India: An Empirical Analysis ${ }^{1}$
}

\author{
SANDHYA R. MAHAPATRO \\ A.N. Sinha Institute of Social Studies, India
}

\begin{abstract}
The objective of this paper is to understand the gender differences in migration patterns at the intra-household level and the socio-economic factors that cause such differences. Furthermore, the paper aims to explore the gender-specific dynamics of migration. The theoretical framework is drawn from the New Economics of Labour Migration model modified to address the gender dimension. In other words, the methodology highlights the linkage between NELM model and empirical evidence in order to understand the influence of gender in the migration decision making process in the household. Data from the National Sample Survey 2007-08 is used, along with the logistic regression technique in order to understand gender differences in migration in a household context. The empirical findings of the study reveal that in poor economic settings the risk of migration of women is higher than that of men within the household, indicating vulnerability of females both as bread winners and care takers. For meeting familial needs and to cope with household income risk most of the females choose migration as a livelihood strategy and therefore they migrate at a higher rate than males. This paper highlights the importance of gender in the household migration decision-making model.
\end{abstract}

\section{Keywords}

Migration, household, gender, risk, NELM model

\section{Introduction}

The changing dynamics of migration in India and its developmental implications are receiving increased attention from researchers, policy makers and planners. Despite the overwhelming share of women $\left(2 / 3^{\text {rd }}\right.$ of migrants evident from Census \& NSS data), the dynamics of female migration in India, like other South Asian countries, is generally neglected. The lower status of women in the household makes them associational mover, those following their male counterpart, and have no role in migration decisions. Since women were conceptualized as accompanying dependents, they were given limited attention in theoretical accounts of migration (Chant and Radcliffe 1992). However, it has since been realised that the causes and consequences of migration in many contexts are different for males and females (Sandbergen 1995). This could be due to the differential economic opportunities that men and women face in recent years, besides the gender inequalities relating to migration decisions within a household. Although women were considered passive actors in the

\footnotetext{
1 The author is thankful to Prof. K.S. James, from the Institute for Social and Economic Change, India for his extremely valuable suggestions and comments and guidance on this paper.
} 
migration process, over time they play an active role in migration decisions, in maintaining family ties and promoting economic improvement of the family (Zachariah et.al. 2000; Kurien 2002; Gallo 2003). While analysing migration patterns from a historical perspective, Hann (2003) pointed out the fact that women from lower economic classes migrated for survival and to escape from patriarchal relations. During the post reform period in India, the transitions in socio-economic structure have had a significant implication on female migration patterns as the causes of their migration. Their role in the migration decision is slowly changing (Shanti 1991; Sundari 2004; Neetha 2004). Given that women's income is lower than men's, women have less control over their income, as well as a higher risk of poverty. Also, meeting the consumption needs of the household may force them to migrate at greater risk and under more pressure. Thus, the feminist studies on migration in recent years suggest that there is a need to understand migration through a gender lens.

Furthermore, the decision to migrate generally takes place with the process of negotiation with other household members. However, in the literature migration is often viewed as an individual strategy and relates to personal characteristics of the migrant. It is the individual and individual characteristics such as demographic attributes, lifecycle stage, attachment to a particular place, social capital, and environmental values that drive migration decision-making (Guangqing and Voss 2005) while others claim that the family is the main decision-making unit, since members of a family usually move together (Mincer 1978). While there is no doubt that the personal characteristic of the individual influence migration decisions, the migrant may not be the sole decision maker. Individuals by themselves cannot decide on migration independently of their households. In many cases it is the family who decides which household members and how many members they will send in order to supplement family income. This recognition has been reflected after the developments in the new economics of labour migration (NELM), which place the issue of migration decision making within the context of the 'household', rather than the individual in which migration is viewed as a household strategy to minimise the element of economic risk (Stark 1991). It is acknowledged in studies that the decision to migrate takes place within the household and it is unlikely that migration can take place solely at an individual level (Banarjee 1981; Bhattacharyya 1985; Aguilera and Massey 2003; Curran and Rivero-Fuentes 2003; Munshi 2003). It is argued that household income, rather than individual income, is the appropriate concept for studying income influence on migration (Tunali 2000). Thus, the household should be considered as an appropriate unit for analysis of the migration decision making process. 
However, the empirical studies, including the NELM model, do not specifically recognise the role of gender in migration decision making at the household level. Possibly, family play a greater role in the case of women's migration because migration of women is very much influenced by familial obligation. In many cases, men make autonomous decisions while women migrate as part of family strategies rather than individual strategies (Boyd 1989; Chant 1992; Hugo 1995). Hence, as migration of females is influenced by familial obligation it needs to be understood from a household perspective. Macro level socio-economic changes such as introduction of new technology, mechanization of agriculture, creation of employment opportunities, and educational institutions in urban areas, influences economic situation of the family that is household income also influences the prospects and motivation for migration differently for males and females.

In view of the assumption that female actions are more tightly bound by household level factors, the migration decisions of females are expected to be more sensitive to the constraints and incentives that households face. The changes in a macro context influence the risk perception of households while adversely affecting women's earning capacity. For instance, the mechanisation process of agriculture does displace many females from agricultural work, but their roles and responsibilities in terms of sustaining the family are relatively more significant than those of males. Under such circumstances, migration for employment becomes the viable option for women. Studies show that the unequal gender division of labour within the household and the marginalisation of women in employment in the place of origin generally induce women to migrate; especially those belonging to poor and landless households (Crummet 2001). Therefore, within a household the way males and females perceive the income risk varies because they confront the livelihood risk differently. Besides, unequal power relations that persist within the household also affect migration decisions differently for males and females. Hence, it can be presumed that female migration behaviour responds to household economic shocks more strongly than that of males, which has not yet been adequately explored in the Indian context.

Addressing the gaps in empirical and theoretical studies, the present study tries to explore the relationship between gender and migration at the intrahousehold level. The major objective of this paper is to understand the gender differences in migration patterns within a household and the factors that attribute to such gender differences. In other words, the paper attempts to explore how the household socio-economic status affects males and females differently with regard to migration decisions in the household. 
Section two will highlight the data and methodology used for the study. The third section will offer an understanding of the female migration situation in India. The fourth section presents gender differences in migration patterns across socio-economic classes for different types of households. The empirical findings of the study are presented in section five, followed by the conclusion.

\section{Data and Methods}

The data for the study has been taken from the national sample survey $64^{\text {th }}$ round data $(2007 / 08)$, as provided by the NSSO for analyzing household migration. It provides employment, unemployment and migration particulars of members from 1, 25, 578 households in India. For analysis both the individual and household data is used. From the individual file we have prepared the household file in order to understand the gender differences in migration. Since marriage is deeply rooted in female migration, this makes it difficult to explore the gender differences and the actual role of females in the migration decision-making process. Thus, those households reporting migration of female due to marriage and family moved are excluded from the analysis. Thus, the focus is more on employment-oriented migration with the capacity to earn a livelihood.

To estimate the gender differences in migration rates at the intra household level, households are classified according to the number of migrants present within a household according to the sex. The migrant households are then classified into: (a) Single migrant households (Households with only one migrant), (b) More than one member migrant households (Households with at least two or more member migrants), (c) Total migrant households (Households with at least one member migrant).

A logistic regression model is used for explaining the intra-household dynamics and gender in migration decision-making. The functional form of the logistic regression model is expressed as,

$$
\mathrm{Y}=\ln (p / 1-p)=\alpha+\beta_{i} \chi_{i}+\mu
$$

Where $i=1,2 \ldots \ldots . n$

To capture the relative risk of migration within a household across gender, ratio of female to male, migration rate is taken as the dependent variable. The dependent variable is dichotomous in nature, taking on value 'zero' and 'one'. 'Zero' represents those households where the female migration rate is less than the male migration rate, and it is 'one' if the female migration rate is greater than the male migration rate. The relative risk ratio of migration for a given household is calculated as Female Migration rate/ 
Male Migration rate.

All the explanatory variables used for the purpose of analysis are classified into three categories, namely economic, demographic and socio-cultural. Maximum educational attainment of household members, caste and religion are included in the analysis as part of the socio-cultural characteristics. The economic variables include the occupation of a household and monthly per capita expenditure. Household size, number of children under age five, number of members aged 60+, and gender composition (sex ratio) of the household are considered as demographic indicators. Using these household indicators, the study tries to understand under what conditions females dominate the migration decision making process within a household. The summary statistics of variables used are presented in Appendix-I.

\section{Female migration in India: Trends, flows and reasons}

Data on migration available from Census, as well as NSS, show a continuous increase in female migration in India. As per the 2001 census of 309 million migrants, 70.7 percent were female. NSS estimates also give a similar picture of female dominance by 80.4 percent. The data extracted from NSS presented in Fig-1 depicts that the overall migration rate is increased from 23 percent in 1983 to 29 percent in 2007/08. This increase is only due to the increasing share of females because while male mobility remains stagnant there is a substantial increase in female mobility from 35 percent in 1983 to 47 percent by 2007/08. This is a reflection of not only an increase in female migration but also the persisting gender difference in migration.

\section{Fig-1: Migration Rate by sex}

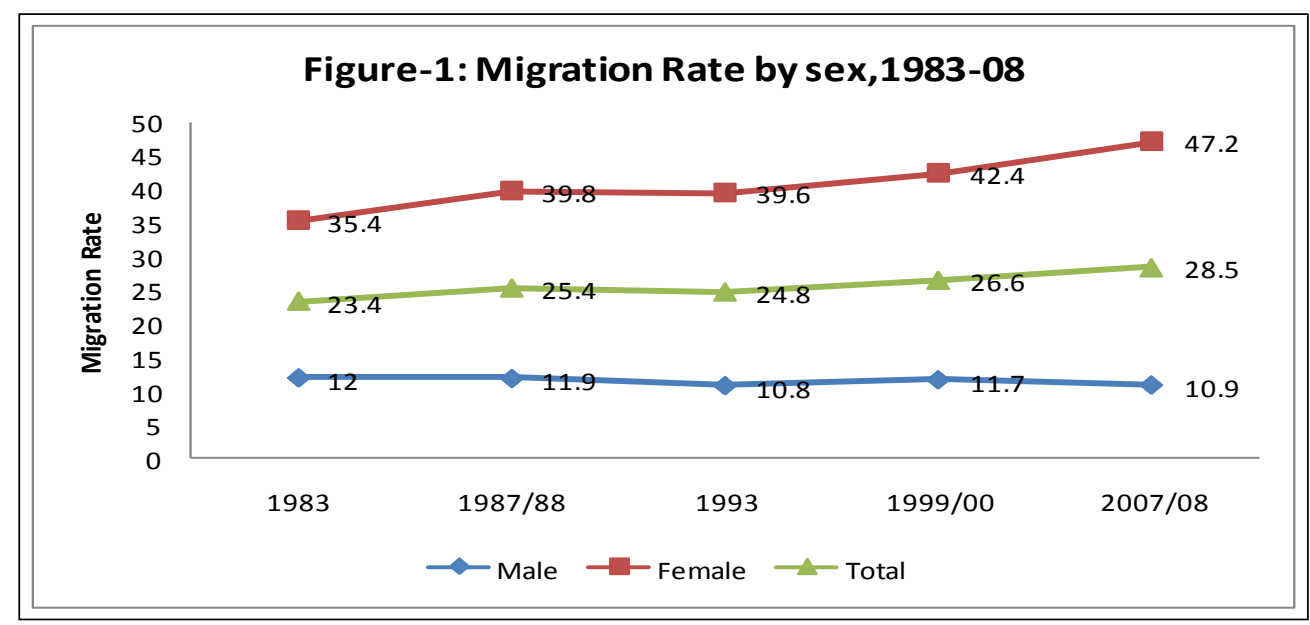


Source: Calculated from NSSO

Among the different categories of migration flow, rural to rural constitutes the major category for migration among females, due to high prevalence of marriage migration. However, over time the levels of rural to urban and urban to urban migration are increasing for employment, education and other reasons. There is overwhelming evidence that internal mobility in India is largely over short distances, and for females is mainly attributed to marriage. However, recently this pattern has been undergoing changes. An inter-temporal analysis of migrants according to the distance shows a number of changes in the pattern of migration (Fig-2). A decrease in intrastate mobility accompanied by an increase in inter-district and inter-state movements has been observed. Such a change in migration patterns, as pointed out in studies, is occurring due to an opening up of the gender segregated labour market, urbanisation, higher education, changing agricultural practices, and environmental hazards (Jayweera et.al. 1994; Gracia 2000; Sundari 2005).

Fig-2: Distribution of Female migrants by distance, 1999/00 $\mathcal{E} 2007 / 08$

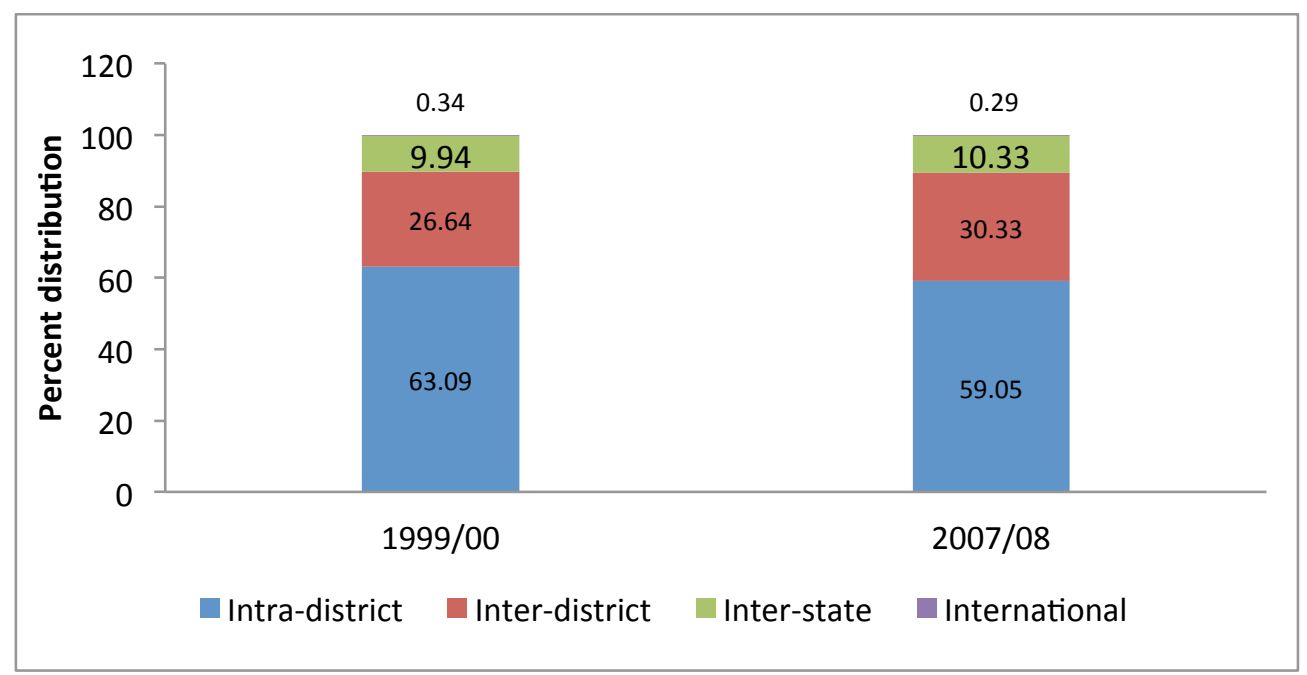

Source: Calculated from NSSO

The disaggregation of female migrants shows that marriage constitutes the major reason for migration with 84 percent. However, in recent years there has been a steady increase in migration of females for education in urban area is observed from 1.3 percent to 2.3 percent. 
The changing flow of females migrating from short distance to long distance, and the increasing mobility of females for education perhaps helps in understanding that, besides changes in motivations of females, the role of females in migration decisions is changing. All these changes in patterns of female mobility indicate that there is also an active involvement of women in migration for reasons other than marriage. Therefore, there is a need to examine the gender differences that persist in migration patterns at the intra-household level.

\section{Gender and Intra-household migration decisions}

A few number of studies conducted using the household as a unit of analysis show the differential impact of household risk factors on migration decisions among males and females. The studies found that the economic status of a household has an inverse relation with female migration, while it increases the chances of male migration (Donato 1993; Cerruti and Massey 2001; Kanaiapuni 2000). Studies conducted on women's migration from Northern Ghana show that households resort to migration in response to worsening of agriculture based livelihoods (Agarwal et al. 1994). In the Indian context, although there is growing awareness of the necessity to understand migration prospects from a gender perspective, there are hardly any studies that focus on analysing the migration behaviour at the household level and from a gender perspective. The increasing migration of females within the framework of the New Economics of Labour Migration (NELM) model can be understood in the present study in terms of the impacts of structural adjustment programmes on the employment patterns of males and females, gender roles and responsibilities and power asymmetries within a household.

To understand the context and how risk perception varies for males and females in terms of migration decision-making, the study analyses the socioeconomic characteristics of migrant households.

The economic status of households in the present study is measured in terms of per capita expenditure (proxy for income), and the household occupational structure. These variables critically influence decision-making regarding migration at the household level.

\section{Household poverty \& migration}

Poorer economic condition of households as being one of the critical factors determining migration decisions has been widely acknowledged in studies. To overcome economic vulnerabilities, such as the lack of employment opportunities and insufficient income, or the inability to meet the economic needs of family members, households (head of household) might decide to migrate either with the entire family, or to diversify its economically active 
members to different places. This enables remittances sent by migrants to help the family members left behind and overcome economic vulnerability. Linking gender, migration and poverty studies show that the risk of poverty within a household is relatively higher among females and therefore, female migration is considered one way of responding to the difficult economic conditions of a family (Findley and Diallo 1993).

Monthly per capita expenditure (MPCE) represents the economic status of a household and is a good proxy for poverty. The variable MPCE is constructed on the basis of a data set by taking into account household expenditure on all consumer durables during the last 365 days and dividing it into five equal expenditure classes ${ }^{2}$. The percentage share of migrant households according to the size across MPCE classes is presented in Table1 .

Table-1: The percentage share of migrant households across economic class by gender (Excluding marriage and family moves), 2007-08

\begin{tabular}{|c|c|c|c|c|c|c|c|}
\hline \multirow{2}{*}{$\begin{array}{l}\text { Monthly per } \\
\text { capita } \\
\text { expenditure } \\
\text { class(in Rs) }\end{array}$} & \multirow[b]{2}{*}{$\begin{array}{l}\text { Total } \\
\text { Number of } \\
\text { Households }\end{array}$} & \multicolumn{2}{|c|}{$\begin{array}{l}\text { Single } \\
\text { migrant } \\
\text { households }\end{array}$} & \multicolumn{2}{|c|}{$\begin{array}{l}\text { More than } \\
\text { one migrant } \\
\text { household }\end{array}$} & \multicolumn{2}{|c|}{$\begin{array}{l}\text { Total migrant } \\
\text { households }\end{array}$} \\
\hline & & $\begin{array}{l}\text { Only } \\
\text { Male }\end{array}$ & \begin{tabular}{|l} 
Only \\
Female
\end{tabular} & $\begin{array}{l}\text { Only } \\
\text { Male }\end{array}$ & \begin{tabular}{|l} 
Only \\
Female
\end{tabular} & $\begin{array}{l}\text { At least } \\
\text { one } \\
\text { Male }\end{array}$ & $\begin{array}{l}\text { At least } \\
\text { one } \\
\text { Female }\end{array}$ \\
\hline Q1(54-1880) & 25,968 & 8.18 & 2.54 & 0.10 & 0.85 & 14.41 & 14.86 \\
\hline Q2(1881-2630) & 21,417 & 3.09 & 0.81 & 0.24 & 0.88 & 10.80 & 11.53 \\
\hline Q3(2631-3515) & 22,671 & 1.83 & 0.58 & 0.36 & 1.23 & 12.46 & 13.21 \\
\hline Q4(3526-5065) & 25,470 & 2.28 & 0.65 & 0.49 & 1.17 & 17.91 & 18.37 \\
\hline $\begin{array}{l}\text { Q5(5066- } \\
198528)\end{array}$ & 30,052 & 3.20 & 1.01 & 0.61 & 1.28 & 31.22 & 31.10 \\
\hline Total & $1,25,578$ & 3.97 & 1.20 & 0.35 & 1.07 & 17.17 & 17.63 \\
\hline
\end{tabular}

Source: Calculated from NSSO data

${ }^{2} \mathrm{Q} 1=$ poorest economic quintile, $\mathrm{Q} 2=$ poorer economic quintile, $\mathrm{Q} 3=$ middle economic quintile $\mathrm{Q} 4=$ richer economic quintile \& $\mathrm{Q} 5=$ Richest economic quintile. 
The percentage of single female migrants is found to be highest in the poorest (Q1) economic class (2.54 percent) followed by the richest (Q5) economic class $(1.01 \%)$ while for the other three middle economic classes the percentage share is lower. The pattern also holds true in the case of single male migrant households. A ' $U$ ' shaped pattern that is slightly flatter in the upper end of migrant households is observed in the case of single migrant households, indicating that the proportion of single migrant households is highest in the poorest class. However, for households with more than one migrant member, the relationship is direct, which indicates that the proportion of migrant households increases with increases in economic class. On the contrary, gender differences in migration for households with two or more migrants indicate that the percentage share of female migrant households is higher than male, irrespective of all economic classes. The percentage share of poorest households (Q1), having two or more male migrants is 0.1 percent, while in the case of females it is 0.85 percent. Similarly, for the richest households (Q5) the share is found to be 0.61 percent for male migrant households and 1.28 percent for female migrant households. Such gender differentials in migration clearly show that in respect of poorer households the relative risk of poverty is greater for female migrants. In the case of total migrant households, there is no significant difference observed between households having at least one female migrant (18 percent) and one male (17.2 percent). The percentage of households with at least one migrant has followed a slightly ' $U$ ' shaped pattern, first declining and then increasing, with increase in economic class for both male and female migrant households. The gender differences in the migration rate for such households suggests that the percentage share of female migrant households is the same or marginally higher than male migrant households. For instance, the percentage share of households with female migrants constitutes 14.8 percent in respect of the Q1 class, while it is 14.4 percent for male migrant households. Similarly, 11 percent of male migrant households are found to have migrated from the Q2 class, while the share amounts to 11.53 percent for female migrant households belonging to the same economic quintile.

The data across consumption expenditure categories shows that out of all the economic classes, the proportion of single female migrant households is higher for the poorest class. This shows that economic deprivation is an important cause of migration for households with single females, although the proportion is relatively less than for male migrant households. This is due to social and cultural constraints. Studies carried out in other countries with regard to independent mobility of women, such as in Latin American countries, show that most of the single women migrating to cities come from lower economic class families. For them, migration is part of the family strategy for survival (Jelin 1977). The independent movement of females is 
thus a direct consequence of the household economic situation. A study by Afshar and Agarwal (1989) shows that women in poor households typically spend almost all their earned income on their family's basic needs, while men keep a significant part of their earnings for extravagant expenditure. It indicates that the role of women as the primary economic providers of the household and their migration appears to be more critically linked to the household welfare as compared to males. In respect of poor households, the economic contribution of women is quite significant in terms of income and the quality of life i.e., the nutritional status of the family and household management (Jayaweera et al. 1994). Linking household income and migration, a study by Prelipceanu (2008) finds that male migrants come from households that have already reached a certain level of material wealth, but women migrants come from poor households because in their case, migration seems to be the 'last best-option'. All this signifies that in poorer households, the role of women as economic providers is quite significant and hence, in the absence of proper earnings to meet the familial needs, women take the decision to move.

Persisting gender differences in migration across higher economic classes for households with two migrants also show that, for enhancing the economic condition of the household in terms of better employment as well as higher education, households with two female migrants show a higher level of mobility compared to male migrant households. This trend has emerged especially in the context of the socio-economic development of the country. For the period 1999/00 (55th round), the proportion of households with two or more male migrants is found to be higher than households with female migrants across economic classes, barring the Q5 quintile. On the contrary, in recent times $(2007 / 08)$ households with female migrants are found to be relatively higher than male migrant households for the same economic class. Perhaps an increase in higher educational institutions and the provision of employment opportunities have motivated females from higher economic groups to migrate. Apart from economic compulsions, a sense of self-sufficiency, economic independence and the desire to prove their worth motivates female households belonging to higher economic groups to migrate (Kaur 2006; Singh 2007). This change in the migration patterns of females also indicates the changing status of women within the household framework and their increasing ability to participate in the household decision making on migration. This implies that economic factors motivate females to migrate to the same extent as they do males.

\section{Occupational structure of households \& migration}

The engagement of households in different employment activities not only shows their present economic status but also helps to understand the factors that persuade a household to migrate. In the present study, households are 
classified into different types on the basis of their major source of income (more than 50 percent) from any gainful activity.

The rural households are divided into five types. These include selfemployed in non-agriculture, agricultural labourers, other labourers, selfemployed in agriculture ${ }^{3}$ and others, while the urban households are divided in to four categories: self-employed, salaried/wage earning class, casual labourers, and others ${ }^{4}$. For the present analysis we have excluded the 'others' category in view of their not being employed. A classification of the household occupational structure after controlling for marriage and family moves is presented in Table-2.

Table-2: The percentage share of migrant households across occupational categories by gender (Excluding marriage and family moves), 2007-08

\begin{tabular}{|c|c|c|c|c|c|c|c|}
\hline \multirow[b]{2}{*}{$\begin{array}{l}\text { Occupational } \\
\text { Categories }\end{array}$} & \multirow[b]{2}{*}{$\begin{array}{l}\text { Total } \\
\text { Number of } \\
\text { Households }\end{array}$} & \multicolumn{2}{|c|}{$\begin{array}{l}\text { Single } \\
\text { migrant } \\
\text { households }\end{array}$} & \multicolumn{2}{|c|}{$\begin{array}{l}\text { More than } \\
\text { one migrant } \\
\text { households }\end{array}$} & \multicolumn{2}{|c|}{$\begin{array}{l}\text { Total migrant } \\
\text { households }\end{array}$} \\
\hline & & $\begin{array}{l}\text { Only } \\
\text { Male }\end{array}$ & $\begin{array}{l}\text { Only } \\
\text { Female }\end{array}$ & $\begin{array}{l}\text { Only } \\
\text { Male }\end{array}$ & $\begin{array}{l}\text { Only } \\
\text { Female }\end{array}$ & $\begin{array}{l}\text { At } \\
\text { least } \\
\text { one } \\
\text { Male }\end{array}$ & $\begin{array}{l}\text { At } \\
\text { least } \\
\text { one } \\
\text { Female }\end{array}$ \\
\hline \multicolumn{8}{|l|}{ Rural } \\
\hline $\begin{array}{l}\text { Self-employed } \\
\text { in non- } \\
\text { agriculture }\end{array}$ & 11,080 & 0.83 & 0.53 & 0.13 & 0.99 & 10.61 & 11.37 \\
\hline $\begin{array}{l}\text { Agricultural } \\
\text { labourer }\end{array}$ & 17,918 & 0.44 & 0.66 & 0.03 & 1.10 & 4.92 & 5.84 \\
\hline Other labourer & 8,789 & 2.56 & 0.45 & 0.18 & 0.96 & 12.44 & 12.80 \\
\hline $\begin{array}{l}\text { Self-employed } \\
\text { in agriculture }\end{array}$ & 28,933 & 0.31 & 0.28 & 0.03 & 1.25 & 4.19 & 5.33 \\
\hline Total & 66,720 & 0.73 & 0.46 & 0.07 & 1.13 & 6.56 & 7.46 \\
\hline \multicolumn{8}{|l|}{ Urban } \\
\hline Self-employed & 16,955 & 3.75 & 0.42 & 0.69 & 1.13 & 28.19 & 27.92 \\
\hline
\end{tabular}

3 Self-employed in agriculture includes cultivation, fishing and other allied activities.

${ }^{4}$ A substantial portion of income from 'other' includes rent, remittance, dividend, interest and others. 


\begin{tabular}{|l|l|l|l|l|l|l|l|}
$\begin{array}{l}\text { Salaried/wage } \\
\text { labourer }\end{array}$ & 17,985 & 11.56 & 1.36 & 1.29 & 0.76 & 48.00 & 46.87 \\
\hline $\begin{array}{l}\text { Casual } \\
\text { labourer }\end{array}$ & 5,119 & 6.62 & 0.99 & 0.94 & 0.42 & 27.64 & 27.10 \\
\hline Total & 40,059 & 7.69 & 0.93 & 1.00 & 0.86 & 37.07 & 36.37 \\
\hline
\end{tabular}

Source: Calculated from NSSO data

The data presented in the table for rural households reveals that out of all types of employment, the proportion of agricultural labourer households with a single female migrant are higher ( 0.66 percent), followed by selfemployed households in non-agriculture activities (0.53 percent) in rural areas. The gender differences in the migration rate show that agricultural labour households with single female migrants are more likely to migrate (0.66 percent), relative to male migrant ( 0.44 percent) households. For households with more than one migrant member, the proportion of female households is higher than male migrant households across all occupational categories. However, the magnitude of difference seems to be higher in the case of agricultural labour households and self-employed households. With regard to the total migrant households, the proportion of female migrant households is higher for self-employed in non-agriculture and agricultural labourer households. A higher share of female migrants in the informally employed households implies that the incidence of poverty within a household pushes females to migrate. This finding is supported by the studies on agricultural labourer households (Gulati 1978) in Kerala, which showed that children's nutritional status is closely linked to the mother's earning rather than the father. Studies conducted in other Asian countries such as rural Thailand and Indonesia show that landless or poor families are more likely to send their daughters out to work, since for these families the daughter's migration is essential if they are to generate income for the family (Pasuk 1982; Speare and Harris 1986).

The occupational desegregation of migrant households in respect of urban areas shows a different picture than in rural areas. For single migrant households, the propensity to migrate is higher for the salaried/wage earning class for both males and females. The share of households with a single male migrant is higher for the salaried/wage earning category (11.56 percent) followed by casual labourer and self-employed categories, which constitute 6.62 percent and 3.75 percent respectively. Likewise, the salaried households with single female migrants constitute the highest share (1.36 percent) followed by the casual labourer category (0.99 percent). Due to 
increased opportunities in urban areas, girls move out from their households at a young age to become economically independent, living on their own in cities so as to be able to send remittances home (Thadani and Todaro 1984).

Household poverty on one hand, and increased employment opportunities in urban areas on the other, both motivate females to migrate in search of employment. Fig-3 shows that most of the female households with single migrants belonging to poor and middle income groups migrate to urban areas in search of employment and also to work as wage labourers. This indicates that poverty is the dominating factor underlying the migration of single women households. With mechanisation and adoption of modern technologies in agriculture, females who are heavily concentrated in agriculture tend to lose their employment.

Fig-3: Single female migration rate for salaried/wage earning household in urban areas by MPCE, 2007/08

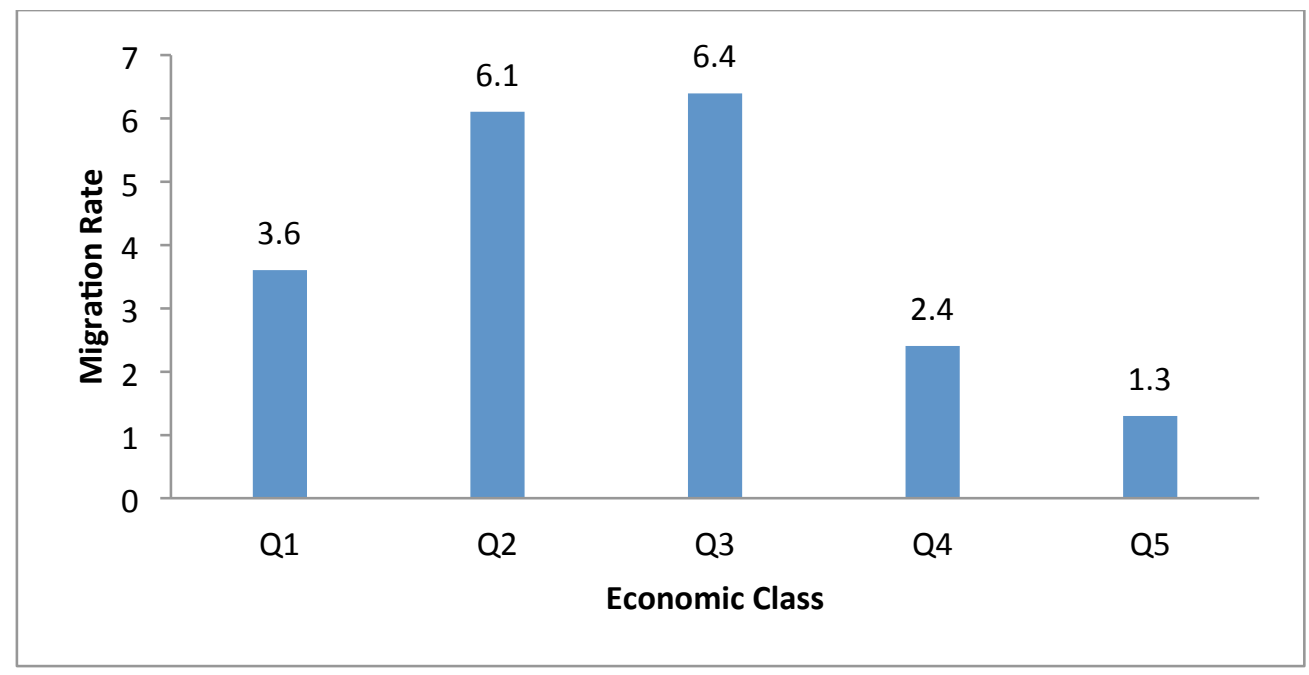

Source: Calculated from NSSO

Besides, employment opportunities for women exist in urban areas, such as low paid industrial jobs and jobs as domestic maids. Therefore, households tend to dispatch their female members to urban areas where they can access employment opportunities in order to support the family. In India, where the traditional norms have long discouraged independent female migration, the commercialisation of agriculture has coincided with a rise in rural-rural seasonal migration among women (Singh 1984). 
Gender differences in the migration rate across occupational categories in urban areas shows that the share of female households with two or more migrants is higher for the self-employed category (1.13 percent) than for male migrant households (0.69 percent). The presence of a higher proportion of households with female migrants in the self-employed category may be due to the notion prevailing in many parts of India that women should not work outside unless driven by extreme conditions. However, they can be compelled to do some jobs because the husband's income is insufficient to meet the growing family needs. At the same time it is also the duty of females to fulfill their domestic responsibilities. Hence, to meet the financial requirements of their families as well as to perform their domestic duties, females are compelled in self-employment activities. Case studies related to India show that families migrated in response to the presence of female oriented economic opportunities (as domestic servants, vegetable vendors, or flower vendors in front of temples) and that they are the primary or equal earners, as male employment is often irregular and uncertain (Premi 2001; Meher 1994). Hence, it can be said that women tend to lead the family migration process because of the relative ease with which they find employment. The other reason for pursuing self-employment is to give their children a better start in life, which is possible only when they migrate to a place where education and health care infrastructure facilities are well developed. A study by Kanaiapuni (2000) shows that women's role in raising their children has always been paramount and that in general, women are in charge of educating their children. This indicates that unlike men, women's mobility is linked more closely to the collective welfare of the family.

The above discussion suggests that macro level changes mediated through household economic factors influence female migration decision-making differently when compared to males within a household.

\section{Educational status of household members \& migration}

It has been widely observed that education is positively related to migration. Higher educational attainments of individual members help households to earn more income, besides enhancing their social status. Since education is an individual level attribute, for the purpose of analysis the maximum educational attainments of the household members have been considered for understanding the migration decision-making process within a household.

Table-3 shows that with an increase in the educational levels of household members, the rate of migration also goes up for both for males and females. The only deviation is observed in respect of single female migrant households. The migration rate of single female migrant households is 
higher for higher educational levels (1.57 percent) followed by illiterate households (1.41 percent) while it declines in respect of the educational levels in-between. The higher rate of single female migrant households from low educational groups indicates the survival strategy of the poor households for employment purpose, as the gender specific labour market provides them with enough scope (Fawcett et al. 1984).

Table-3: The percentage share of migrant households according to educational attainment of family members by gender (Excluding marriage $\mathcal{E}$ family moves), 2007/08

\begin{tabular}{|l|l|l|l|l|l|l|l|}
\hline & & \multicolumn{2}{|l|}{$\begin{array}{l}\text { Single migrant } \\
\text { households }\end{array}$} & \multicolumn{2}{l|}{$\begin{array}{l}\text { More than one } \\
\text { migrant } \\
\text { households }\end{array}$} & \multicolumn{2}{|l|}{$\begin{array}{l}\text { Total migrant } \\
\text { households }\end{array}$} \\
\cline { 3 - 8 } $\begin{array}{l}\text { Educational } \\
\text { status of } \\
\text { household } \\
\text { members }\end{array}$ & $\begin{array}{l}\text { Total } \\
\text { Number of } \\
\text { Households }\end{array}$ & $\begin{array}{l}\text { Only } \\
\text { Male }\end{array}$ & $\begin{array}{l}\text { Only } \\
\text { Female }\end{array}$ & $\begin{array}{l}\text { Only } \\
\text { Male }\end{array}$ & $\begin{array}{l}\text { Only } \\
\text { Female } \\
\text { least } \\
\text { one } \\
\text { Male }\end{array}$ & $\begin{array}{l}\text { At least } \\
\text { one } \\
\text { Female }\end{array}$ \\
\hline Illiterate & 11,482 & 2.46 & 1.41 & 0.09 & 0.85 & 8.47 & 8.98 \\
\hline Primary & 29,569 & 3.67 & 0.98 & 0.20 & 0.98 & 11.34 & 12.02 \\
\hline $\begin{array}{l}\text { Middle/Secon } \\
\text { dary }\end{array}$ & 46,602 & 3.43 & 1.03 & 0.35 & 0.99 & 15.42 & 15.91 \\
\hline $\begin{array}{l}\text { High } \\
\text { secondary \& } \\
\text { above }\end{array}$ & 37,925 & 5.73 & 1.57 & 0.60 & 1.37 & 29.56 & 29.70 \\
\hline Total & $1,25,578$ & 3.97 & 1.20 & 0.35 & 1.07 & 17.17 & 17.63 \\
\hline
\end{tabular}

Source: Calculated from NSSO data

With regard to all other types of households, the share of migrant households increases with an increase in the educational levels of household members. For total migrant households, there is no significant gender difference observed in the migration rate. A higher migration rate of females from highly educated households indicates that females migrate to other places with a view to improving the overall quality of life in the long run. Perhaps the new macroeconomic processes affect different categories of 
women differently, depending upon their economic class 5 . Hence, it can be said that female migration can be attributed to economic reasons with respect to the poor households, and to better of quality life and upward social mobility in the case of higher educated groups.

The above discussion highlights the fact that single female migrant households are more vulnerable and poverty ridden. The presence of a higher proportion of single female migrant households is observed in respect of low economic group households. This indicates that independent mobility of women mostly takes place for ensuring the survival of their families. In the case of single migrant households, the male mobility rate is found to be higher than the female mobility rate across the socio-economic classes. On the other hand, with regard to other types of households, gender differences in the migration rate shows that female migration is on par with male migration across socio-economic groups, and in some instances even higher than males.

All these findings suggest that women migrate in order to become the main economic providers of the household in many instances, especially in the poor socio-economic context. Similarly, females from better off socioeconomic background also migrate for the overall enhancement of the socioeconomic status of their households, like males, to a large extent.

\section{Gender differences in determinants of intra-household migration}

In order to understand the gender differences in migration within a household and the major factors influencing it, a logistic regression model is applied. This model predicts the log of odds of female to male migration rates (the magnitude greater than one) vs. female to male migration rates (the magnitude less than one), which is a function of various intrahousehold socio-economic and demographic variables.

\footnotetext{
5 Poor marginalised women are compelled to join the informal sector for ensuring the survival of their families. For middle class women, finding employment in the formal sector becomes a must to maintain a minimum middle class standard of living. The upper middle class women are also drawn in to the labour market by an inner urge to do something creative and to prove their worth (Singh 2007).
} 
Table-4: Logistic regression analysis predicting the likelihood of female to male migration rate in the context of intra-household dynamics (Outside marriage and family moves), 2007-08

\begin{tabular}{|c|c|c|c|}
\hline $\begin{array}{l}\text { Ratio of female migration rate } \\
\text { to male migration rate }\end{array}$ & Odds Ratio & Std. Err. & $\mathbf{z}$ \\
\hline \multicolumn{4}{|l|}{ Economic variables } \\
\hline \multicolumn{4}{|l|}{ Poverty (Poorest) } \\
\hline Poor & $0.819^{*}$ & 0.099 & -1.65 \\
\hline Middle & $0.802^{* *}$ & 0.093 & -1.9 \\
\hline Richer & $0.695^{* * *}$ & 0.080 & -3.15 \\
\hline Richest & $0.604^{* * *}$ & 0.072 & -4.21 \\
\hline \multicolumn{4}{|l|}{ Employment(labourers) } \\
\hline Service & $0.765^{* * *}$ & 0.057 & -3.59 \\
\hline Cultivators & $1.455^{* * *}$ & 0.128 & 4.24 \\
\hline Petty traders \& worker & $0.718^{* * *}$ & 0.054 & -4.4 \\
\hline \multicolumn{4}{|l|}{ Demographic variables } \\
\hline HHSIZE & 0.939 & 0.038 & -1.58 \\
\hline HHSIZE square & $1.010^{* *}$ & 0.003 & 2.17 \\
\hline Children Under age 5 & $0.690^{* * *}$ & 0.035 & -7.37 \\
\hline Aged (60+) & $2.113^{* * *}$ & 0.119 & 13.25 \\
\hline Sex ratio & $0.240^{* * *}$ & 0.008 & -43.89 \\
\hline \multicolumn{4}{|l|}{ Socio-Cultural variables } \\
\hline \multicolumn{4}{|l|}{ Caste(Others) } \\
\hline ST & 1.118 & 0.105 & 1.19 \\
\hline SC & 1.040 & 0.080 & 0.51 \\
\hline
\end{tabular}




\begin{tabular}{|l|l|l|l|}
\hline OBC & $1.097^{*}$ & 0.062 & 1.62 \\
\hline Religion(Hindu) & & & \\
\hline Muslim & 1.046 & 0.085 & 0.55 \\
\hline Others & 1.122 & 0.097 & 1.33 \\
\hline $\begin{array}{l}\text { Educational attainment of } \\
\text { household members (Illiterate) }\end{array}$ & & & \\
\hline Primary & 0.993 & 0.148 & -0.05 \\
\hline Secondary & 0.968 & 0.141 & -0.23 \\
\hline Higher Secondary \& above & 0.996 & 0.151 & -0.03 \\
\hline N & 11370 & & \\
\hline LR chi2(20) & $3321.28^{* * *}$ & & \\
\hline Pseudo R2 & 0.242 & & \\
\hline
\end{tabular}

${ }^{*} \mathrm{p}<0.1,{ }^{* *} \mathrm{p}<0.05,{ }^{* * *} \mathrm{p}<0.01$

Source: Estimated from NSSO

The effect of MPCE on migration shows that the odds of migration are lower than the reference category (Poorest) for households, where female migration is higher than male migration. This implies that females from poorer households are more likely to migrate than males from the same household. Thus, household poverty is a major predictor of female migration decision making. This finding can be linked to the studies on gender and migration showing that in the case of poor households, the economic responsibility of females in terms of childcare and meeting basic household needs is higher than males. Hence, it can be said that income variance of a household increases the probability of migration to a relatively higher degree for females.

For the multivariate analysis, the occupational status of households is divided into four categories, including service (includes technician/professional/ clerical and other related work), cultivator, petty trader and labourer (agricultural and other labourers) for analysis. We have considered labourer as classified by NSSO as a reference category in the analysis. After controlling for other factors, compared to households 
belonging to the labourer class (reference category), the odds of migration are lower for females belonging to the service and petty worker categories. Higher odds of female migration relative to males in the labourer household category indicates that the role of women as the major economic providers of the households and the uncertainty of regular income flow motivate them to migrate.

The odds of migration for females are found to have increased by 1.45 times in respect of the cultivator household category. It would be logical to argue that the decision of a household regarding a particular occupation depends upon the relative income level of the family and other responsibilities. Although cultivators do not belong to the poorest group, in view of an uncertain income flow from agriculture on the one hand, and mechanisation of agriculture on the other, females are pushed out of agriculture, thereby increasing their migration rate.

Demographic factors such as family size, presence of small children, elder (aged60+), and the gender composition of the households have been analysed to locate the gender differences in the migration decision making at the intra-household level.

A positive and significant impact of household size squared on the odds of migration is observed from the analysis. This result is consistent with the new economic migration theory, that it is plausible for a household with a large family size to encourage migration by providing a diversified source of income and, hence, controlling for the level of risk. For females, large households can provide substitutes in terms of managing household tasks. Studies related to family size and migration in Asian and Latin American countries show that the larger the size of a family, the greater is the push for females (rather than males) to migrate. While sons are needed for the family agricultural activities, daughters are often viewed as additional mouths to feed, and hence their migration is encouraged (Findlay and Diall 1993).

The presence of dependents in a household increases the odds of migration for females compared to males, whereas, women who have children less than 5 years old are less likely to migrate. To take care of dependent children, females tend to move less often relative to males. Studies show that married women with higher numbers of children are less likely to migrate, since they rarely leave their children with their families to share the child rearing responsibilities (Brown 1983; Sinha 1975).

The gender composition of households shows that the presence of an additional female member in a household lowers the odds of female migration compared to male. It is likely that households with greater numbers of female members get marginalised and may not able to bear the 
migration cost, which deters their migration propensity. A cross classification of MPCE and sex-ratio of households shows that around 30 percent of households belong to the poorest class where female members are high, whereas the figure is 15 percent in those households where the sex-ratio is low (NSS 2007/08).

The odds of migration are higher for females belonging to the $\mathrm{OBC}$ category compared to males,. This shows that caste as an economic as well as a social constraint pushes females into migration to a larger extent than males. However, other socio-cultural variables do not have any impact on their migration.

Moreover, the findings of the multivariate analysis show that in a poorer economic set up, the economic role and responsibilities of females are greater than those of males and hence, the risk of poverty is higher for females than for males. The macro level economic changes create a substantial income risk for females which influences their risk aversion behaviour. The intra-household gender based division of labour and responsibilities thus shape the propensity of females to migrate differently to males.

\section{Conclusion}

This present study provides an economic explanation of the gender differences underlying the migration decision-making process within a household framework. It highlights that female migration outside marriage and associated movement is basically a response to the socio-economic status of a given family. Women recourse to migration as a practical strategy in order to cope with household vulnerabilities, minimise the income risk and improve the economic status of the family. This tendency is found to be higher in the case of single female migrant households. However, gender differences in the migration rate of single migrant households show that the socio-cultural norms do not favour the free mobility of single females as they do in the case of males. However, with respect to the all other household categories consisting of more than one migrant, households with female migrants show a higher migration tendency than male migrant households.

The results of the logistic regression model elicit the role of household socioeconomic factors in determining the female migration decision making at the intra-household level. The findings illustrate that females from low economic classes, low social groups as well as those engaged in informal employment migrate disproportionately at a higher rate than males from the same household. This implies that the relative differential in the risk of migration is higher for a female than that of a male in poorer households. 
To take care of the family needs and to cope with household income risk most females decide on migration as a livelihood strategy for the family as a whole. This implies that it is the economic compulsion within the household that mainly drives the migration of households that have female members.

What emerges from the overall discussion is that women play a major role in the -household migration process in terms of ensuring the economic stability of their families. While linking gender with household migration, it is observed that the degree of influence of household factors on risk minimisation and the migration decision making of females is higher than for males. This paper, thus, brings out the importance of gender in the household migration decision making model, as it reveals sometimes striking differences in the determinants of migration, i.e. the influence of household risk factors for both men and women. Higher migration rates of females relative to males in certain household factors may also prompt one to think about changing the gender role of females in a household.

\section{References}

Afshar, Haleh and Bina Agarwal (1989) Women, Poverty and Ideology in Asia. London: Macmillan.

Agarwal, Bina (1994) A Field of One's Own: Gender and Land Rights in South Asia. Cambridge: Cambridge University Press.

Aguilera, M. and D. S. Massey (2003) Social Capital and the Wages of Mexican Migrants: New Hypotheses and Tests. Social Forces, 82(2), 671-701.

Banerjee, Nirmala (1985) Women Workers in the Unorganized Sector: The Calcutta Experience. Hyderabad: Orient Longman.

Bhattacharyya, B. (1985) The role of family decisions in internal migration: The case of India. Journal of Development Economics, 18(1), 51-66.

Boyd, M. (1989) Family and personal networks in international migration: Recent developments and new agendas. International Migration Review, 23(3), 638-670.

Brown, E.K.A. (1983) Patterns of Internal Migration in Ghana, With Special Emphasis on the Determinance of Female Migration. Unpublished Doctoral Dissertation submitted to University of Pennsylvania.

Cerrutti, M. and D. S. Massey (2001) On the Auspices of Female Migration from Mexico to the United States. Demography, 38(2), 187-200. 
Chant, S. and Radcliffe, S.A. (1992) Migration and development: the importance of gender. In S. Chant (ed.) Gender and migration in developing countries. London: Belhaven Press, 1-29.

Chant, S. (1992) Towards a framework for the analysis of gender selective migration. In Chant, S. (ed.) Gender and Migration in Developing Countries. Belhaven Press, London, pp. 197 - 206.

Crummet, M. (2001) A Gendered Economic History of Rural Households, Calvillo, Aguascalientes, Mexico, 1982-1991. Frontiers: A Journal of Women's Studies, 22 (1): 105-125.

Curran, S. R. and E. Rivero-Fuentes (2003) Engendering Migrant Networks: The Case of Mexican Migration. Demography, 40(2), 289-307.

De Haan, A. (2003) Calcutta's Labour Migrants: Encounters with Modernity. In K. Gardner and F. Osella (eds.) Migration, Modernity and Social Transformation in South Asia (special issue of Contributions to Indian Sociology, 37(1\&2), 189-216.

Donato, K. M. (1993) Current Trends and Patterns of Female Migration: Evidence from Mexico. International Migration Review 27(4), 748-771.

Fawcett J.T., Khoo, S. and Smith P.C. (1984) Women in the Cities of Asia: Migration and Urban Adaptation. Boulder, Colorado: West View Press.

Findley, Sally and A. Diallo (1993) Social appearances and economic realities of female migration in Rural Mali. In Internal Migration of Women in Developing Countries. United Nations Department for economic and social information and policy analysis. New York, United Nations.

Gallo, E. (2003) Unorthodox Sisters: Gender Relations and Transnational Marriages among Malayali Migrants in Italy. Sussex Migration Working Paper no. 17.

Garcia, Brigida (2000) Women, Poverty and Demographic Change. New York: Oxford University.

Guangqing, Chi and Paul Voss (2005) Migration Decision-Making: A Hierarchical Regression Approach. The Journal of Regional Analysis and Policy, 35(2), 11-22.

Gulati, L. (1978) Profile of a female agricultural labourer. Economic and Political Weekly, 13(12), 27-36.

Hugo, G. (1995) International labour migration and the family: Some observations from Indonesia. Asian Pacific Migration Journal, 4(2/3), 273-301. 
Jayaweera, Swarna, Malsri Dias, Nerda, Weekakoon and Goonewarderne (1994) Women and Poverty: The Experience of Accelerated Mahawelli Development Programme in Sri Lanka. In N. Heyzer and G. Sen (eds.) Gender. Economic Growth and Poverty: Market Growth and State Planning in Asia. New Delhi: Asia Pacific Development Center Publishing Limited.

Jacob, Mincer (1978) Family Migration Decisions. Journal of Political Economy, 86(5), 749- 73.

Jelin, E. (1977) Migration and Labour Force Participation in Latin American Women: The Domestic Servants in the Cities. In The Wellesley editorial committee (eds.) Women and National Development. Chicago: University of Chicago Press.

Kanaiaupuni, Shawn, M. (2000) Reframing the Migration Question: An Analysis of Men, Women, and Gender in Mexico. Social Forces, 78(4), 131148.

Kaur, Ravinder (2006) Migrating for Work: Rewriting Gender Relations. In Sadhana, Arya and Anupama Roy (ed.) Poverty, Gender and Migration. New Delhi: Sage Publications.

Kurien P. (2002) Kaleidoscopic Ethnicity. International Migration and the Reconstruction of Community Identities in India. New Brunswick (N.J.): Rutgers University Press.

Meher, Rajkishor (1994) The Migrant Female Breadwinners: Women in the Informal Secondary Sector of Rourkela, Orissa. Indian Journal of Labour Economics, 37(3), 449-64.

Munshi, K (2003) Networks in the modern economy: Mexican migrants in the US labor market. Quarterly Journal of Economics, 1(18), 549-99.

Neetha, N (2004) Making of Female Breadwinners: Migration and Social Networking of Women Domestics in Delhi. Economic and Political Weekly, 39(17):1681-88.

Pasuk, P (1982) From Peasant Girls to Bangkok Masseuses. International Labour Office.

Prelipceanu, Raluca (2008) A Gendered Approach to Temporary Labour Migration and Cultural Norms: Evidence from Romania in International Seminar on Economic Migration, Institute for Economic Forecasting and the Sorbonne Centre of Economics, Bucharest 13-15 June.

Premi, M. K (2001) Who Migrates to Delhi. Demography India, 30(1), 49-59. 
Rosenzweig, Mark, R. and Odded, Stark (1989) Consumption Smoothing, Migration, and Marriage: Evidence From Rural India. Journal of Political Economy, 97(4), 905-26

Singh, A. M. (1984) Rural to Urban Migration of Women in India: Patterns and Implications. In J.T. Fawcett, S. Khoo, and P.C. Smith (eds.) Women in the Cities of South Asia: Migration and Urban Adaptation. Colorado: West View Press.

Sinha, G. P and Ranade, S. N. (1975) Women Construction of Workers. Bombay: Allied Publishers.

Singh, Vinita (2007) Women Domestics: Workers within households. New Delhi: Rawat Publication.

Shanti, K. (1991) Issues Relating to Economic Migration of Females. The Indian Journal of Labour Economics, 34(4), 335-46.

Speare, A. and Harris, J. (1986) Education, Earnings and Migration in Indonesia. Economic Development and Cultural Change, 34(2), 223-44.

Stark, Odded (1991) The Migration of Labour. Massachusetts: Blackwell Publishers.

Sundari, S. (2005) Migration as a Livelihood Strategy: A Gender Perspective. Economic and Political Weekly, 2295-2302.

Thadani, V.N. and Todaro, M.P. (1984) Female migration: A Conceptual Framework. In J.T.Fawcett, S.E.Khoo and P.C.Smith (eds.) Women in the cities of Asia. Boulder, Colorado: Westview Press.

Tunali, Insan (2000) Rationality of Migration. International Economic Review, 41(4), 893-920.

Zachariah K.C., Mathew E.T., and Irudaya R. (2000) Dynamics of Migration in Kerala: Dimensions, Differentials and Consequences. Thiruvanathapuram (Kerala), Centre for Development Studies 
Appendix-I: Summary Statistics of variables used in the Regression Model

\begin{tabular}{|l|l|l|l|l|l|}
\hline Variable & Observation & Mean & $\begin{array}{l}\text { Std. } \\
\text { dev }\end{array}$ & Min & Max \\
\hline Economic Variables & & & & & \\
\hline MPCE & 125578 & 4182.14 & 3459.83 & 54 & $\begin{array}{l}19582 \\
8\end{array}$ \\
\hline Service & 125578 & 0.26 & 0.44 & 0 & 1 \\
\hline Cultivator/fishery & 125578 & 0.26 & 0.44 & 0 & 1 \\
\hline Petty trader/worker & 125578 & 0.16 & 0.37 & 0 & 1 \\
\hline Labourer & 125578 & 0.22 & 0.41 & 0 & 1 \\
\hline $\begin{array}{l}\text { Demographic } \\
\text { Variables }\end{array}$ & & & & & \\
\hline Household size & 125578 & 4.56 & 2.33 & 1 & 34 \\
\hline Household size square & 125578 & 26.21 & 30.58 & 1 & 1156 \\
\hline Children under age 5 & 125578 & 0.34 & 0.47 & 0 & 1 \\
\hline Aged 60+ & 125578 & 0.28 & 0.45 & 0 & 1 \\
\hline $\begin{array}{l}\text { Socio-cultural } \\
\text { Variables }\end{array}$ & 125578 & 0.32 & 0.47 & 0 & 1 \\
\hline General/Others & 125578 & 0.30 & 0.46 & 0 & 1 \\
\hline SC/ST & 125578 & 0.37 & 0.48 & 0 & 1 \\
\hline OBC & 125578 & 0.77 & 0.42 & 0 & 1 \\
\hline Hindu & 0.12 & 0.32 & 0 & 1 \\
\hline Muslim & 0.11 & 0.31 & 0 & 1 \\
\hline Other religion & & & & & 1 \\
\hline Illiterate & & & & & \\
\hline
\end{tabular}


Gender and intra-household migration decision in India, Mahapatro

\begin{tabular}{|l|l|l|l|l|l|} 
Primary & 125578 & 0.24 & 0.42 & 0 & 1 \\
\hline Middle/Secondary & 125578 & 0.37 & 0.48 & 0 & 1 \\
\hline $\begin{array}{l}\text { Higher secondary \& } \\
\text { above }\end{array}$ & 125578 & 0.30 & 0.46 & 0 & 1 \\
\hline
\end{tabular}

Source: Calculated from NSSO data 